\title{
Creating a writing course to improve the writing self-efficacy of graduate nursing students
}

\author{
Lisa B. Robinson, Mary Bishop \\ Tanner Health System School of Nursing at University of West Georgia, Carrollton, GA, United States
}

Received: May 1, 2017

DOI: $10.5430 / \mathrm{cns} . v 5 \mathrm{n} 4 \mathrm{p} 88$
Accepted: September 20, $2017 \quad$ Online Published: September 27, 2017

URL: https://doi.org/10.5430/cns.v5n4p88

\begin{abstract}
Objective: Contemporary advanced professional nursing requires the ability to communicate effectively in written and oral forms. Many registered nurses enter graduate nursing school with experience writing in medical records but with no experience writing scholarly papers or writing for publication. This article describes the development, implementation and evaluation of a writing course developed in an online graduate nursing program in the southeastern United States. The goal of this research was to determine if graduate nursing students' writing self-efficacy increased after the completion of a newly developed one-credit online writing course.

Methods: Fifty-three first-semester graduate nursing students participated in a 16-week online asynchronous writing course developed at a school of nursing. The course instructors designed writing experiences with the goal of increasing writing competency. The faculty defined writing competence as achieving mastery of the necessary writing skills to produce an organized, logical, understandable message containing the effective use of language, grammar, and punctuation.

Results: The students' writing self-efficacy increased significantly from pretest and posttest. The results revealed a significant increase in self-efficacy scores with the second administration of the tool. The mean of the 20-question Likert scale pretest was 70.59. Results obtained after the conclusion of the course resulted in a mean of 80.12. The finding of a mean increase of 9.529 was found to be statistically significant.

Conclusions: The information from this research can be used to develop effective strategies to support online graduate students with their writing skills. This experience highlights the fact that we cannot leave the development of academic writing to chance. Achieving academic writing success requires structured instruction, practice and frequent feedback from faculty who have the passion for and expertise in scholarly writing.
\end{abstract}

Key Words: Writing, Self-efficacy, Graduate nursing, Scholarly writing

\section{INTRODUCTION}

Graduate education in the United States plays a crucial role in the success of the U.S. workforce and economy. ${ }^{[1]} \mathrm{Be}-$ tween 2008 and 2018, the number of jobs requiring a master's degree will grow by more than two million, an increase of 18\%. ${ }^{[1]}$ More recently, it was noted that newly graduated masters' degree employees need critical skills, such as oral and written communication. ${ }^{[2]}$ However, many students who enter graduate school are unable to express themselves competently via written communication. ${ }^{[3-6]}$ Academic writing is assumed to be a scholarly activity for which graduate students are already competent. However, the acquisition of writing skills is a long-term learning process requiring personal practice, critical thinking, considerable effort, and

\footnotetext{
* Correspondence: Lisa B. Robinson; Email: lisarobinsonnp@ gmail.com; Address: Tanner Health System School of Nursing at University of West Georgia, Carrollton, GA, United States.
} 
training activities. ${ }^{[7,8]}$

Most graduate students write without assistance and tend to find academic writing challenging and stressful. ${ }^{[3,9]}$ These students often look to university faculty members or oncampus writing centers for guidance. In turn, faculty offer support to assist with writing, but may lack the time and knowledge to guide students adequately. With the growth of $100 \%$ online asynchronous graduate courses, the ability of students to access in-person writing support services has decreased. In the fall of 2015 , there were more than six million students taking at least one distance course, having increased by $3.9 \%$ over the previous year. This growth rate was higher than seen in either of the two previous years. This equates to $29.7 \%$ of all students in higher education are taking at least one distance course. ${ }^{[10]}$

Asynchronous online learning with the lack of face-to-face interaction brings new challenges for both faculty and graduate students. Many graduate students enrolling in $100 \%$ online asynchronous online programs have been out of school for many years, are juggling the competing demands of work and family and may require academic and writing support that is only available in face-to-face classes. ${ }^{[4]}$ As programs and enrollment in online graduate education grow, it becomes essential to examine the unique characteristics and needs of online graduate learners to help them be successful in online environments. $^{[4]}$

\subsection{Research objectives}

The goals of a nursing program, whether at the master's or doctoral level, include instilling knowledge, improving critical thinking, and developing effective oral and written communication skills. If any of these areas are deficient, it is less likely students will be successful. For nursing seeking advanced degrees, written communication skills are needed to document patient care, write and revise policies, develop and update educational materials, and write for publication.

The faculty of the School of Nursing at a southeastern U.S. university frequently expressed concern about the lack of quality writing of its graduate students. They identified a need to improve the writing abilities of their graduate nursing students enrolled in $100 \%$ online asynchronous programs, specifically related to content, writing mechanics, grammar, and APA formatting. The faculty expressed concerns related to improving the quality of graduate student writing. After multiple meetings, the graduate nursing faculty revised the Masters of Science in Nursing and the Doctor of Education in nursing curriculums to add a one-credit online, asynchronous graduate academic writing course to the first-semester plan of study.

\subsection{Literature review}

One of the essential components of scholarship and graduate education is academic writing. Successful academic performance relies on academic writing skill, which is rarely taught. ${ }^{[11,12]}$ Successful academic writing entails planning, deductive reasoning, comprehension, and the synthesis of new knowledge. All of these attributes are skills grounded in the cognitive domain. While writing is necessary for success as a graduate student, many students enter graduate school unable to express themselves via academic writing. ${ }^{[3-6,13,14]}$

Often, professors expect students to have proficiency in basic writing skills. ${ }^{[15]}$ However, in a national study, only $40 \%$ of students graduating from 4-year colleges were competent in the required knowledge and cognitive skills needed for academic writing. ${ }^{[16]}$ Switzer and Perdue ${ }^{[17]}$ noted that twothirds of the students who came to a graduate writing center lacked the skills to conduct a comprehensive literature search and to write academically.

The social theory of self-efficacy served as the theoretical background for the study. ${ }^{[18]}$ Bandura defined self-efficacy as the "belief in one's capabilities to organize and execute the courses of action required to produce given attainments". [19] Self-efficacy has been shown to be a consistent and reliable predictor of students' performance on tasks. Bandura theorized that individuals choose to engage in certain tasks based on their perception of success or failure. ${ }^{[20]}$ Individuals reflect on their abilities to carry out the task but also try to predict what the outcome will be based on the contemplated course of action. ${ }^{[21]}$

Individuals' self-efficacy development is also predisposed by their personality, feelings, capabilities, prior experience with similar behavior or actions, encouragement from others, and the situation in which the action occurs. Self-efficacy beliefs directly affect all successive actions. Thus, self-efficacy is demonstrated to be a better predictor of performance than factors such as actual performance or ability. ${ }^{[22]}$ Learners with advanced levels of self-efficacy are more likely to set higher, but reachable goals and will persist to achieve the goals. ${ }^{[23]}$ Students with low self-efficacy tend to set lower goals, apply less effort, and lack persistence, leading them to quit if the goal becomes too difficult. In the academic context, self-efficacy helps students decide how much effort, resilience, and persistence to apply to an assignment. ${ }^{[24]}$

Pajares defined writing self-efficacy as the learner's commitment to complete the writing task. ${ }^{[25]}$ The noteworthy positive relationship between students' self-efficacy beliefs and their writing performance were found in several studies. ${ }^{[26-28]}$ In higher education, where graduate students typically exhibit higher levels of academic skills, self-efficacy 
beliefs could be a key factor for academic success. Writers' self-efficacy beliefs interact with their intrinsic motivation to achieve their writing outcomes. ${ }^{[29,30]}$ The lack of self-efficacy to carry out writing assignments can impede students' academic progress. ${ }^{[25,30,31]}$ When faced with a demanding assignment, people who have high self-efficacy will meet the challenge as something to be studied and conquered. Their motivation and drive to learn the task will push them to succeed in their challenging, yet attainable goal. ${ }^{[32]}$ If met with failures or setbacks, the student with high efficacy will not give up; whereas, students with low self-efficacy are likely to decide that the task is unachievable. ${ }^{[32]}$ Researchers have demonstrated the benefits of self-efficacy beliefs on the degree of effort, the ability to persist, performance, and goal setting. ${ }^{[33,34]}$ Writing self-efficacy theory offers a way to measure the difference in graduate students' beliefs in their writing ability using the theory developed and tested by Bandura.

Noteworthy positive relationships between students' selfefficacy beliefs and their writing performance have been found in several studies. Hidi and Boscolo ${ }^{[35]}$ noted that investigators for more than two decades had found positive associations between writing self-efficacy and writing outcomes. Students expect that their efforts will bring about positive results, ranging from simply passing the course to full mastery. ${ }^{[25,36]}$ Students have a set of beliefs about the value of learning and expected benefits. If students do not value the learning, they are unlikely to be motivated and engaged. ${ }^{[25,30]}$

Pajares and Valente ${ }^{[37]}$ pointed to research on beliefs about writing methods and competencies that are instrumental to students' success as writers. Miller, Russell, Cheng, and Skarbek ${ }^{[38]}$ measured writing self-efficacy in undergraduate nursing students enrolled in an online writing course. The Post-Secondary Writerly Self-Efficacy Scale was used to measure the change in self-efficacy before and after the writing course. Significant improvements in all self-efficacy scales were found. ${ }^{[38]}$

Although the concept of self-efficacy has been applied to writing in general self-efficacy has not been studied with online graduate nursing students. ${ }^{[25,37]}$ There is a gap in the literature on how to develop the writing skills of online graduate nursing students. Using social cognitive theory to study graduate student writing is a necessary step to determine if the intervention of a one-credit writing course fostered the growth of writing self-efficacy.

The growth of online learning underscores the need for quality academic writing support to help $21^{s t}$-century online graduate nursing students' academic success. The goal of this research project was to determine if the one-credit writing course provided to the online graduate nursing students' increased their sense of writing self-efficacy.

\section{Methods}

\subsection{Sample and process}

Fifty-three first-semester graduate nursing students participated in a 16-week online asynchronous writing course developed by two faculty members and the writing specialist at the School of Nursing. Research in writing literacy demonstrates that students' self-efficacy and motivation are increased when teaching strategies are used that model desired writing and communication skills. ${ }^{[39,40]}$ The course instructors designed writing experiences with the goal of increasing writing competency. The faculty defined writing competence as achieving mastery of the necessary writing skills to produce an organized, understandable message of logical organization and containing the effective use of language, grammar, and punctuation. The researchers were not involved in designing or teaching the course.

There was no face-to-face or scheduled web-based instruction. The faculty modeled writing competencies in their class announcements and discussion posts. The students were motivated by constructive feedback and achievement of individual goals related to writing. No grades were assigned for individual assignments and the students received a satisfactory or unsatisfactory grade at the end of the course. Content elements of the writing intervention focused on: (1) developing the central message, (2) logically organizing the writing, (3) choosing effective vocabulary, (4) using writing mechanics correctly, and (5) concisely presenting the work with linkages between concepts.

Students wrote papers based on assignments in their other first semester courses. Assignments were scaffolded over the semester based on writing complexity and difficulty. Coursework became increasingly complex as students drew from their learning, and incorporated research evidence to develop an annotated bibliography related to their future capstone project. Student work was evaluated by both course faculty and classmates via a peer review process using a standardized writing assessment rubric. The writing specialist coached students who had difficulty developing their writing skills.

\subsection{Measurements}

Mastery of tasks, motivation, reduction in stress, negative feelings, and social persuasion form the elements of Bandura's theory. ${ }^{[41]}$ These concepts have been translated into scales that assess elementary students' writing self-efficacy by focusing on the writing product rather than process. Schmidt and Alexander ${ }^{[42]}$ recognized that these scales could 
not assess college student writing or the process of writing. Therefore, Schmidt and Alexander, assisted by the staff of the Writing Center of Western Oregon University, developed the Post-Secondary Writerly Self-Efficacy Scale (PSWSE). The PSWSE is a 20-item question that uses a 5-point Likert scale to evaluate overall writing self-efficacy on a scale from 1 (strongly disagree) to 5 (strongly agree). Higher scores indicated higher writing self-efficacy. Specific items are used to create three subscales: (1) local and global writing and process knowledge, (2) physical reaction to writing, and (3) time and effort required for writing assignments.

Permission was obtained from the creators of the PSWSES to use the tool. Potential participants received an email invitation in the second week of the class asking them to participate in an anonymous online pretest survey. Students were provided a link to the PWSES instrument at an online survey platform. Three weeks before the course ended, the students were again provided a link to the PWSES instrument. To maintain anonymity, but also to permit matching of pre and post surveys, participants received instructions in the pretest email invitation to create a unique identification number. Data from each survey were downloaded, responses matched by the students' unique identification number, and analyzed using the SPSS software program. Twenty-one pairs of pretest and posttest questionnaires were used in the analyses.

\section{RESULTS}

\subsection{Research question 1}

Was there a significant difference in the pretest and posttest writing self-efficacy scores of graduate nursing students who participated in a mandatory one-credit hour online writing course?

Three subscale scores and an overal writing self-efficacy score were calculated and assessed using paired-samples $t$ tests. In each case, the students's self-efficacy scores were signficantly higher at posttest than at pretest (see Table 1).

Table 1. Pretest/posttest differences in writing self-efficacy scores $(n=21)$

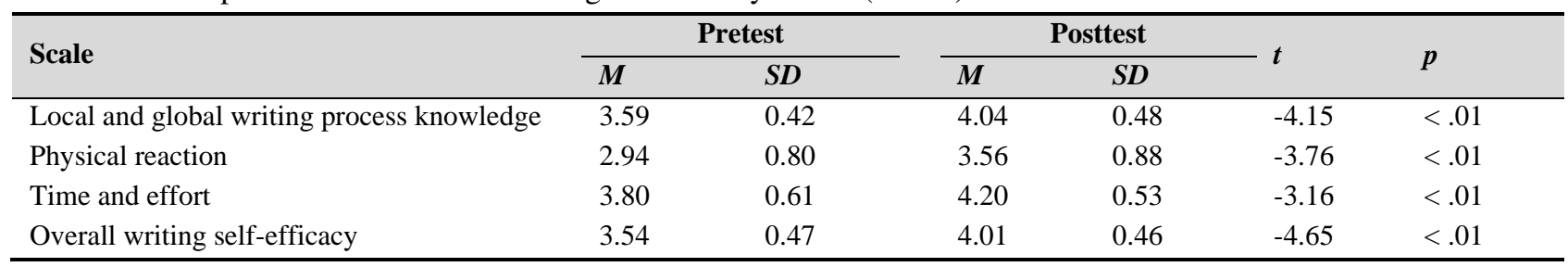

\subsection{Research question 2}

What were the possible reasons for the changes in writing self-efficacy scores after the students participated in a mandatory one-credit hour online writing a course?

Two faculty members taught 53 new master's and doctoral students in five sections of the writing course. At the end of the course the students completed an anonymous 22-item online evaluation of the class. The University's online learning department administered and analyzed the survey. The students responded to the items using a 5-point Likert scale that ranged from 1 (strongly disagree) to 5 (strongly agree). Higher scores indicated agreement with the statements which were all written in the affirmative. Three subscales were created from the 22 Likert-scaled items. The subscales focused on the students' evaluation of their participation in the course, their feelings about the content and assignments, and the effectiveness of the instructors demonstrating their knowledge of the content and in explaining course materials as well as the evaluation process. Sixty-two percent $(n=33)$ of the 53 students responded to the survey (see Table 2).

Overall for the seven items on student participation, the students reported that they were actively engaged in their learning and were prepared for the class by using the course materials. They all felt the course challenged their intellect and that they were well prepared for class. For the six questions related to the course content, the students in four of the five sessions felt that the course assignments helped them understand the concepts of scholarly writing as well as requiring them to problem solve, think critically, and be creative in their thought processes. The lowest score was related to the how the course content was effectively presented but the majority agreed or strongly agreed that the course-assignments - as well as discussions and activities helped them to understand the subject matter. The students in Section 5 were beginning doctoral students and reported that the course content was not as effective for their learning.

The students agreed or strongly agreed to the nine questions on instructor effectiveness. All students strongly agreed that the instructors demonstrated respect for them as well as being receptive and responsive to sharing ideas and being available for individual assistance. The students responded strongly that the intstructor demonstrated knowledge of the discipline 
of writing and explained course expectations. All students agreed that they knew how they would be evaluated in the course and that assignments were graded in a imely fashio.
The lowest score was for the question the instructor presents material in an organized fashion which ties to the low score on the effective presentation of the material.

Table 2. Means of student course evaluation subscales by course section

\begin{tabular}{lllllll}
\hline \multirow{2}{*}{ Section } & Instructor & \multirow{2}{*}{$\begin{array}{l}\text { Respondents/students } \\
\text { in class }\end{array}$} & \multirow{2}{*}{$\begin{array}{l}\text { Response rate } \\
(\boldsymbol{\%})\end{array}$} & \multicolumn{3}{c}{ Evaluation subscale } \\
\cline { 5 - 6 } & & & $\begin{array}{l}\text { Student } \\
\text { participation }\end{array}$ & $\begin{array}{l}\text { Appropriatene } \\
\text { ss of content }\end{array}$ & $\begin{array}{l}\text { Effectiveness of } \\
\text { instructor }\end{array}$ \\
\hline 1 & 1 & $11 / 13$ & 85 & $4.7^{*}$ & 4.4 & 4.5 \\
2 & 1 & $6 / 14$ & 43 & 4.8 & 4.7 & 4.7 \\
3 & 1 & $7 / 14$ & 50 & 4.4 & 4.6 & 4.6 \\
4 & 2 & $4 / 5$ & 80 & 4.6 & 4.4 & 4.6 \\
5 & 2 & $5 / 8$ & 63 & 4.2 & 3.5 & 4.2 \\
All sections & & 33 & 62 & 4.5 & 4.3 & 4.5 \\
\hline
\end{tabular}

Note. ${ }^{*}$ mean of scale ranging from 1 (strongly disagree) to 5 (strongly agree)

Additionally, the students could respond to five open-ended questions which were in addition to the previously discussed items. The sixteen respondents wrote 64 responses to the five open-ended questions. Sixty of the comments were postive and four were written negatively.

When asked how they will use the knowledge gained in the writing course in future classes, there were thirteen comments which were all positive. One student wrote that, "I will utilize the knowledge to continue to improve my writing." Another students stated, "The knowledge I gained from this course will assist me throughout graduate school." A student wrote that she has more confidence in writing her papers while another rstated they understood how to complete a synthesis of literature.

For the question "What was the most important thing they learned in the course?", many students mentioned they learned APA formatting, as well as learning to write a scholarly paper. One student commented, "I learned the definition of scholarly writing and its concepts." Another student stated, "I learned how to synthesize the literature and how to outline a scholarly paper while two others stated they appreciated the feedback for improvement." Seven comments focused on the fact that they felt they would be more successful in future classes as they had a foundation of knowledge related to scholarly writing.

Students responded to the question on what positive changes that need to be made in the course. Three comments were written negatively in that more information on the completion of course assignments was needed as well as coordination of assignments with the faculty teaching other courses. Two students felt the course should be offered as a prereguiste for admission to the graduate program.

As far as the question on the evaluation methods used there were eight comments that were positive in that the evaluation methods used were fair and were clear. One negative comment was made on the grading systems as there were no numerical grades, rather the terms satisfactory or unsatisfactory were used. The student felt that that numerical grades should have been applied.

The final question asked students to comment on the instructor's overall effectiveness in the discipline. All respondents stated that the instructors were fair and understanding as they provided excellent feedback. One student commented made the following comment "This was very helpful for a first time online student learning the meaning of scholarly writing. Another student wrote". It is genius to start with a writing course like this one to equip students with the tools to express themselves properly at the start of their pursuit of their Master's degree.

\subsection{Research question 3}

Did the assignments in the writing course meet the course and program learning outcomes?

This one-hour credit course had one learning outcome. Students were to demonstrate knowledge of basic writing skills, including basic structure and rules of the English language. Assignments designed to achieve this outcome included discussion board posts, an annotated bibliography, a literature review, a reflective writing, and a plagiarism quiz. The instructors designed the course to scaffold assignments during the course. For the literature review assignment, students used the same articles they had used previously in the annotated bibliography assignment. All students who enrolled in the course completed it and passed with a grade of satisfactory.

A course review meeting with the instructors was held at the

ISSN 2324-7940 E-ISSN 2324-7959 
end of the semester. The instructors reported that students had difficulty throughout the course determining the expectations of the assignments. For example, the students reported having no experience writing a review of the literature and were unsure how to begin the assignment. Students made the same comments about the other assignments.

The course assignments were designed to introduce students to the specific content needed later in their program of study. The learning outcome of the course, to demonstrate knowledge of basic writing skills was met by the assignments. Students who completed assignments needed varying degrees of writing support throughout the semester to revise sentence and paragraph structure and to follow basic rules of English writing. While the instructors teaching the course and the evaluation results from the students indicated the course learning outcome was met the instructors continued to revise and update the course each time it is taught. The addition of content related to identifying and avoiding plagiarism was an important concept the instructors wanted to add to the course.

\section{Discussion}

Development and implementation of a graduate-level online asynchronous academic writing course was based on the identified need for writing support of graduate students. This provided the opportunity for an analysis of the impact of the newly implemented course on the self-efficacy of the participant students. Results demonstrate a statistically significant increase in writing self-efficacy in this group of students.

One key finding, the course, as evaluated by the students, was seen as valuable. This correlates with the research intent, the course does improve self-efficacy. Many of the graduate students reported having been years out from their undergraduate degrees, felt a lack of confidence in their academic writing abilities. Self-efficacy scores increasing in the post-course evaluation was congruent with the comments made by students through the course evaluations with reports of improvements in self-confidence. Several students commented on feeling empowered to begin academic writing assignments and better understanding the time and effort required for assignments at the graduate school level.

While the course was taught and evaluated in a school of nursing at a state university, several of the faculty teaching various sections of the course sought support and information on resources from a trained writing assistant. This demonstrates an additional key finding of the importance of specialty trained and designated writing assistance. The usual responsibilities of the nursing school writing assistant were to assist graduate students in thesis and dissertation work.
The writing assistant was able to help and direct faculty to help individual students with the greatest writing needs. Additonally, this correlates with the current research available that students will seek out writing assistance from faculty and writing centers, when assistance is available. ${ }^{[3]}$

Going forward, the ability to refine the content of the course certainly exists. An early intervention necessary for the course is an enhanced alignment of the course with learning outcomes of the graduate nursing program. Beyond the accreditation demands, moving the content of the course to better prepare students for more precise information on content expectations of the entire program is needed. Another issue discovered by the faculty teaching the course, which was unexpected, was the need by many students for basic writing instruction. Examples include support with sentence structure, finding academic journal articles for reference use, and for some, explanation of the expectations associated with academic writing. Considerations for the development of a method to evaluate the writing skills of incoming students could allow for dividing the students into groups where the observed deficits are addressed together.

From the faculty perspective, an observed potential area of improvement would be ensuring the faculty teaching sections of the writing course have available to them resources which are accurate, current and presented on the same level. Some variations in the writing skills set of the faculty were noted. Inquiry into the writing experience of the faculty varied widely. While some members of the faculty had written a thesis or dissertation in their graduate programs, other members of the faculty had completed graduate programs for nurse practitioners and clinical nurse specialist and not had an emphasis on academic writing in their graduate programs. Discussions on ways to evaluate and foster the academic writing skills of the faculty are ongoing.

\section{Conclusions}

A clear increase in students' self-efficacy was demonstrated using the PSWSES tool. The first sub-theme of the instrument, assessing local and global writing process knowledge saw an increase in score of over 5 points from the pretest to the posttest. The relevance of this finding is consistent with the current literature, when assistance with writing is available to students, it will be utilized. The second sub-theme findings reflect a decrease in physical reaction to academic writing for the students. This finding is significant, especially since the required amount of academic writing in graduate school programs can be substantial. The third sub-theme findings demonstrate a decrease in the amount of time required by students to locate resources and complete writing assignments. The importance of this information relates to 
the limited time many graduate students have to complete graduate school assignments while also working full time as a professional. Increasing writing knowledge, decreased physical aversion to academic writing, and increased efficiency in completing writing assignments could increase the likelihood of successful graduate school completion. The information from this research will be used to develop effective strategies to support online graduate students with their writing skills. This experience highlights the fact that we cannot leave the development of academic writing to chance. Achieving academic writing success requires structured instruction, practice and frequent feedback from faculty who have the passion for and expertise in scholarly writing.

\section{CONFlicts OF InTEREST Disclosure}

The authors declare they have no conflicts of interest.

\section{REFERENCES}

[1] Wendler C, Bridgeman B, Cline F, et al. Council of Graduate Schools and Educational Testing Service: The Path Forward: The Future of Graduate Education in the United States. Report from the Commission on the Future of Graduate Education in the United States. Princeton, NJ: Educational Testing Service; 2010.

[2] Wendler C, Bridgeman B, Markle R, et al. Council of Graduate Schools and Educational Testing Service: Pathways through Graduate School and into Careers. Report from the Commission on Pathways through Graduate School and into Careers. Princeton, NJ: Educational Testing Service; 2012.

[3] Bair M, Mader C. Academic writing at the graduate level: improving the curriculum through faculty collaboration. Journal of University Teaching and Learning Practice. 2013; 10(1): 1-13.

[4] Milman N. Crafting the "right" online discussion questions using the Revised Bloom's Taxonomy as a framework. Distance Learning. 2015; 11(4): 17-20. Available from: https ://www.usdla.org/wp - content/uploads/2015/09/Vol.-11-No. -4-2014.pdf

[5] Mullen C. Best writing practices for graduate students: reducing the discomfort of the blank screen. Kappa Delta Pi Record. 2006; 43(1): 30-35. https ://doi.org/10.1080/00228958.2006.10 516456

[6] Singleton-Jackson JA, Lumsdend D. Johnny still can't write, even if he goes to college: a study of writing proficiency in high education graduate students. Current Issues in Education. 2009; 12(10): 1-39.

[7] Elder L, Paul P. Critical thinking and the art of substantive writing; Part II. Journal of Developmental Education. 2006; 29(3): 38-39.

[8] Zimmerman BJ, Kitsantas A. Acquiring writing revision skill: Shifting from process to outcome self-regulatory goals. Journal of Educational Psychology. 1999; 91(2): 241-250. https ://doi .org/10.1 037/0022-0663.91.2.241

[9] Nelson JS, Range LM, Ross MB. A checklist to guide graduate students' writing. International Journal of Teaching and Learning in Higher Education. 2012; 24(3): 376-382.

[10] Allen I, Allen J. Digital Learning Compass: Distance Education Enrollment Report 2017, Babson Survey Company. 2017. Available from: https://onlinelearningsurvey.com/reports/digti allearningcompassenrollment2017.pdf

[11] Borglin G. Promoting critical thinking and academic writing skills in nursing education. Nurse Education Today. 2012; 32: 611-613. https://doi.org/10.1016/j.nedt.2011.06.009

[12] Cameron J, Nairn K, Higgins J. Demystifying Academic Writing: Reflections on Emotions, Know- how and Academic Identity. Journal of Geography in Higher Education. 2009; 33(2): 269-284. https://doi.org/10.1080/03098260902734943
[13] Shirey MR. Building scholarly writing capacity in the Doctor of Nursing Practice program. Journal of Professional Nursing. 2013; 29(3): 137-147.

[14] Alter C, Adkins C. Improving the writing skills of social work students. Journal of Social Work Education. 2001; 37: 483-505.

[15] Collier P, Morgan D. "Is that paper due today?" Differences in the first generation and traditional college students 'understanding of faculty expectations. Higher Education. 2008; 55(4): 425-446. https ://doi.org/10.1007/s10734-007-9065-5

[16] Baer JD, Cook AL, Baldi S. The literacy of America's college students. Washington, D.C.: American Institutes for Research; 2016. Available from: http://www.air.org/resource/literacy-a mericas-college-students

[17] Switzer A, Perdue SW. Dissertation 101: A research and writing intervention for education graduate students. Education Libraries. 2011; 34(1): 4-14.

[18] Bandura A. Social foundations of thought and action; A social cognitive theory. Englewood Cliffs, NJ.: Prentice -Hall; 1986.

[19] Bandura A. Social Learning Theory. Prentice-Hall: Englewood Cliffs; 1977.

[20] Bandura A. Self-efficacy: The exercise of control. New York, W.H: Freeman; 1997.

[21] Schunk DH. Self-efficacy for reading and writing: influence of modeling, goal setting, and self-evaluation. Reading and Writing Quarterly. 2003; 19: 159-172. https://doi.org/10.1080/105735603082 19

[22] Bandura A. Self-efficacy. In V.S. (Ramachandran Ed.) Encyclopedia of human behavior (4). New York: Academic Press; 1994. 71-81 p.

[23] Schunk DH. Self-efficacy and education and instruction. In: Maddux, J.E. (Ed.), Self-efficacy, Adaptation, and Adjustment: Theory, Research, and Application. New York: Plenum Press; 1995. 281-303 p. https : //doi.org/10.1007/978-1-4419-6868-5_10

[24] Hetthong R. Does writing self-efficacy correlate and predict writing performance? International Journal of Applied Linguistics \& English Literature. 2013; 2(1): 157-167. https://doi.org/10.7575/ij alel.v.2n.1p.157

[25] Pajares F. Self-efficacy beliefs, motivation and achievement in writing. A review of the literature. Reading \& Writing Quarterly. 2003; 19: 159-172. https://doi.org/10.1080/10573560308222

[26] Erkan DY, Saban A. Writing performance relative to writing apprehension, self-efficacy in writing and attitudes towards writing. A correlational study in Turkish tertiary-twelve EFL. The Asian EFL Journal Quarterly. 2011; 13(1): 162-192.

[27] Shah PM, Mam H, Wan M, et al. Self-efficacy in the writing of Malaysian ESL learners. World Applied Sciences Journal (Innovation and Pedagogy for Lifelong learning). 2011; 145: 8-11. 
[28] Woodrow L. College English writing effect: Self-efficacy and anxiety. System. 2011; 39: 510-522. https : //doi.org/10.1016/j.syst em. 2011.10 .017

[29] Prat-Salam M, Redford P. Writing essays: does self-efficacy matter? The relationship between self-efficacy in reading and writing and undergraduate students' performance in essay writing. Educational Psychology. 2011; 32(1): 9-20. https ://doi.org/10.1080/01 443410.2011 .621411

[30] Zimmerman BJ, Bandura A. The impact of self-regulatory influences on the development of writing proficiency. American Educational Research Journal. 1994; 31: 845-862. https ://doi .org/10. 310 2/00028312031004845

[31] Klassen RM. A question of calibration: A review of the self-efficacy beliefs of students with learning disabilities. Learning Disability Quarterly. 2002; 25(2): 88-103. https://doi.org/10.2307/15 11276

[32] Pujaris F, Schunk D. Self-beliefs and school success: Self-Efficacy, self-concept, and school achievement. In R. Riding \& S. Rayner (Eds.), Perception. London: Ablex Publishing; 2001. 239-266 p.

[33] Pajares F. Towards a positive psychology of academic motivation. The role of self-efficacy beliefs, In R. Gilman, E.S. Huebner \& M.J. Furlong (Eds.), Handbook of positive psychology in schools. New York: Taylor and Francis; 2009. 149-160 p.

[34] Chen MC, Lin H. Self-efficacy, foreign language anxiety as predictors of academic performance among professional program students in a general English proficiency writing test. Perceptual and Motor Skills. 2009; 420-430. PMid: 20037996. https ://doi.org/10. 2 466/pms . 109.2.420-430
[35] Hidi S, Boscolo P. Motivation and writing. In C.A. MacArthur, S. Graham and J. Fitzgerald (Eds.), Handbook of Writing research. New York: The Guilford Press; 2008. 144-157 p.

[36] Schunk DH, Swartz CW. Goals and progress feedback: effects on self-efficacy and writing achievement. Contemporary. Educational Psychology. 1993; 18(3): 337-354. https ://doi.org/10.1006/ ceps. 1993.1024

[37] Pajares F, Valainte G. Self-efficacy beliefs and motivation in writing development in C.A. MacArthur, S. Graham and J. FitzGerald's (Eds), Handbook of writing research. New York: The Guilford Press; 2008. 159-170 p.

[38] Miller L, Russell C, Cheng A, et al. Evaluating undergraduate nursing students' self-efficacy and writing competence: Effects of a writing intensive intervention. Nurse Education in Practice. 2015; 15(3): 174 180. PMid: 25726136. https ://doi.org/10.1016/j.nepr. 201 4.12 .002

[39] Schunk DH. Learning theories: An educational perspective (7th ed.). Boston: Pearson Education; 2016.

[40] Zimmerman BJ. Self-efficacy: an essential motive to learn. Contemporary Educational Psychology. 2000; 25(1): e82-91. https : //doi.org/10.1006/ceps.1999.1016

[41] Zimmerman BJ, Cleary TJ. Adolescents' development of personal agency: the role of self-efficacy beliefs and self-regulatory skill. In: Pajares, F., Urban, T. (Eds.), Self-efficacy Beliefs of Adolescents. Greenwich: Information Age Publications; 2005. 45-69 p.

[42] Schmidt K, Alexander J. The Empirical Development of an Instrument to Measure Writer Self-Efficacy in Writing Centers. The Journal of Writing Assessment. 2012; 5(1): 1-19. Available from: http://www. journalof writingassessment.org/art icle.php?article $=62$ 